\title{
Epstein-Barr virus related post-transplant lymphoproliferative disorder prevention strategies in allogeneic hematopoietic stem cell transplantation
}

Julian Lindsay ${ }^{1,2 *}$, Michelle K. Yong ${ }^{2,3,4}$, Matthew Greenwood ${ }^{1,5}$, David CM Kong, ${ }^{2,6,7,8}$, Sharon C-A Chen ${ }^{2,9}$, William Rawlinson ${ }^{10}$, Monica Slavin ${ }^{2,3,4}$

1. Haematology Department, Royal North Shore Hospital, Sydney, Australia

2. National Centre for Infection in Cancer, Peter MacCallum Cancer Centre, Melbourne, Australia

3. Department of Infectious Diseases, Peter MacCallum Cancer Centre, Melbourne, Australia

4. Sir Peter MacCallum Department of Oncology, University of Melbourne, Parkville, Australia

5. University of Sydney, Sydney, Australia

6. National Centre for Antimicrobial Stewardship at The Peter Doherty Institute for Infections and Immunity, Parkville, Victoria, Australia

7. Centre for Medicine Use and Safety, Faculty of Pharmacy and Pharmaceutical Sciences, Monash University, Parkville, Victoria, Australia

8. Pharmacy Department, Ballarat Health Services, Ballarat, Victoria, Australia, Australia

9. Centre for Infectious Diseases and Microbiology, New South Wales Health Pathology and Westmead Hospital, The University of Sydney, and the Marie Bashir Institute for Infectious Diseases and Biosecurity, The University of Sydney, Sydney, Australia

10. SAViD (Serology and Virology Division), NSW Health Pathology, Prince of Wales Hospital, and SOMS, BABS and School of Women's and Children's Health, University of New South Wales, Sydney, Australia

*Corresponding author: julian.lindsay@health.nsw.gov.au 0294631128 Haematology Department, Royal North Shore Hospital, Reserve Road, St Leonards 2065 NSW, Australia

Wordcount: approx. 3500

\section{Keywords:}

Epstein-Barr related Post-transplant Lymphoproliferative Disorder, EBV-PLTD, allogeneic hematopoietic stem cell transplantation.

\author{
Abbreviations: \\ allo-HSCT; Allogeneic hematopoietic stem-cell transplantation \\ ATG; Anti-Thymocyte Globulin \\ CTL; Cytotoxic T Lymphocyte \\ EBV; Epstein-Barr Virus \\ GVHD; Graft versus Host Disease \\ PBMC; Peripheral blood mononuclear cells \\ PTLD; Post-Transplant Lymphoproliferative Disorder \\ TCD; T-cell depleted \\ WB; Whole blood
}

This is the author manuscript accepted for publication and has undergone full peer review but has not been through the copyediting, typesetting, pagination and proofreading process, which may lead to differences between this version and the Version of Record. Please cite this article as doi: $10.1002 / \mathrm{rmv} .2108$ 


\section{Running Head:}

EBV PTLD prevention strategies in alloHSCT

This article is protected by copyright. All rights reserved. 


\section{Summary}

Epstein-Barr virus associated post-transplant lymphoproliferative disorders (EBV PTLD) are recognized as a significant cause of morbidity and mortality in patients undergoing allogeneic hematopoietic stem cell transplantation (alloHSCT). The number of patients at risk of developing EBV PTLD is increasing, partly as a result of highly immunosuppressive regimens, including the use of anti-thymocyte globulin (ATG). Importantly, there is heterogeneity in PTLD management strategies between alloHSCT centres worldwide. This review summarises the different EBV PTLD prevention strategies being utilized including the alloHSCT and Tcell depletion regimes and the risk they confer; monitoring programs, including the timing and analytes used for EBV virus detection, as well as pre-emptive thresholds and therapy with rituximab. In the absence of an institution specific policy, it is suggested that the optimal preemptive strategy in HSCT recipients with T-cell depleting treatments, acute graft vs. host disease (GVHD) and a mismatched donor for PTLD prevention is, i) monitoring of EBV DNA post-transplant weekly using plasma or WB as analyte and, ii) pre-emptively reducing immune suppression (if possible) at an EBV DNA threshold of >1,000copies/mL (plasma or WB), and treating with rituximab at a threshold of $>1000$ copies/mL (plasma) or $>5,000$ copies $/ \mathrm{mL}$ (WB). There is emerging evidence for prophylactic rituximab as a feasible and safe strategy for PTLD, particularly if pre-emptive monitoring is problematic. Future management strategies such as prophylactic EBV specific CTLs have shown promising results and as this procedure becomes less expensive and more accessible, it may become the strategy of choice for EBV PTLD prevention.

This article is protected by copyright. All rights reserved. 
This article is protected by copyright. All rights reserved. 


\section{Introduction}

Epstein-Barr virus associated post-transplant lymphoproliferative disorders (EBV PTLD) are recognised as a significant cause of morbidity and mortality in patients undergoing allogeneic hematopoietic stem cell transplantation (alloHSCT). ${ }^{1}$ Before the year 2000, an attributable mortality for EBV PTLD after HSCT was reported as $86 \%$ at 1 year post-transplant. ${ }^{2}$ With the introduction of new approaches to prevention and treatment of EBV PTLD such as monitoring for EBV DNA levels using nucleic acid testing (NAT) of peripheral blood, pre-emptive therapy and timely treatment with rituximab or cytotoxic T lymphocytes (CTLs), patient outcomes have improved substantially. However, current mortality rates associated with EBV-PTLD following an allogeneic HSCT (allo-HSCT) are still of concern, at 30\%-55\%. ${ }^{3,4}$ Moreover, there is heterogeneity in management strategies used between alloHSCT centres internationally. ${ }^{5,6}$ With a recent increase in the use of anti-thymocyte globulin (ATG) in alloHSCT to reduce the risk of GVHD, the number of patients at risk of developing EBV PTLD is increasing. ${ }^{7-10}$ This review summarises, and provides a contemporary perspective of the management strategies to prevent EBV PTLD in an era of increasing alloHSCT using T-cell depleted regimens.

\section{Background}

EBV belongs to the genus Lymphocryptovirus, subfamily Gammaherpesvirinae, family Herpesviridae. ${ }^{11}$ In immunocompetent hosts, primary EBV infection is predominantly asymptomatic, occasionally causing an infectious mononucleosis in adolescents or young adults. EBV establishes a life-long latent infection in B-cells, controlled by T-lymphocytes and 
NK cells. However, in immunocompromised hosts, particularly with T-cell depletion, EBV initiates a latent growth, causing naïve B-cells to transform into proliferating blasts. ${ }^{11}$

EBV PTLD are lymphoid and/or plasmacytic proliferations that occur following a solid organ transplantation or alloHSCT due to immunosuppression. ${ }^{1}$ Although the vast majority of PTLD are related to the presence of EBV, EBV-negative disease does occur. Also referred to as EBV lymphoproliferative disease (LPD), EBV PTLD is the result of the outgrowth of EBVinfected B-cells that would normally be controlled by an effective EBV-specific cytotoxic Tcell response. ${ }^{12}$ This occurs due to a disruption to the normal balance between latently infected B-cell proliferation and an EBV-specific T-cell response, in which the increased number of latently infected B-cells develop into PTLD, typically presenting with lymphadenopathy or nodules, which may be localized or present as diffuse disease. Non-specific constitutional symptoms such as fever, weight loss, and fatigue are also common. ${ }^{13,14}$

PTLD in alloHSCT recipients is most commonly donor-derived and thought to be due to the proliferation of EBV-infected B-cells in the absence of active T-cell immune surveillance. In a alloHSCT donor infected with EBV, there is an estimated one per million transformed B-cells carrying the virus that are "held in check" by cytotoxic T-cells, resulting in an equilibrium between cell division and death of EBV-infected B-cells. ${ }^{12}$ However, when mature T-cells are depleted from a graft, EBV-transformed B-cells may escape from cytotoxic T-cell surveillance, increasing the risk of PTLD. Risk factors for the development of PTLD post HSCT are shown in Table 1.

\section{T-cell depletion (TCD) and EBV PTLD}


Initial studies in recipients of alloHSCT that were selectively T-cell depleted (TCD) to prevent GVHD demonstrated EBV reactivation in 65\% of recipients, with approximately $20 \%$ of these developing EBV PTLD. ${ }^{15}$ The study suggested that an elevated EBV DNA load was predictive for developing EBV PTLD, as no patients with a viral load $\leq 1,000 \mathrm{gEq} / \mathrm{mL}$ developed PTLD. The threshold of $1,000 \mathrm{gEq} / \mathrm{mL}$ however, provided a relatively poor positive predictive value for the development of PTLD, with only 39\% of patients developing PTLD above this viral load. ${ }^{15} \mathrm{~A}$ follow up study which included a broader range of HSCT recipients showed that only $50 \%$ of patients with elevated EBV DNA (defined as $>4,000$ copies/ $\mu$ g PBMC EBV DNA) subsequently developed PTLD, however there were no patients that developed PTLD with negative PCR results. ${ }^{16}$

ATG has been widely incorporated into alloHSCT conditioning regimens as part of GVHD prophylaxis in many transplant centres internationally. ${ }^{17}$ ATG is used as a form of in vivo donor T-cell depletion as well as depleting host T-cells that remain after the conditioning regimen. ${ }^{18}$ Therefore, a major consideration when using ATG is the increased risk of EBV viremia and subsequent risk of EBV PTLD due to a reduction in active T-cell immune surveillance against EBV-infected B-cells. In a large phase 3 trial by Walker et al. comparing rabbit ATG versus no ATG in alloHSCT conditioning to reduce the incidence of GVHD, 33\% of patients in the ATG arm had EBV reactivation compared with 3\% who did not receive ATG. ${ }^{7}$ However, other similar randomised controlled studies such as Kroger et al. reported fewer EBV reactivations (3.6\% with ATG vs $1.4 \%$ without ATG). ${ }^{19}$ This effect may be due to the type of ATG used, with Walker et al. using $4.5 \mathrm{mg} / \mathrm{kg}$ Thymoglobulin ${ }^{\mathrm{TM}}$ and Kroger et al. using 30mg/kg of Fresenius ${ }^{\mathrm{TM}}$ ATG. Finke et al. also used Fresenius ${ }^{\mathrm{TM}}$ ATG at a total dose of 
$60 \mathrm{mg} / \mathrm{kg}$, in which $5 \%$ of patients in the ATG arm developed EBV PTLD, of which 3 of 5 patients died. ${ }^{20}$ Routine EBV monitoring was not mandatory and subsequently the EBV reactivation rate was not reported. Increased EBV reactivation has also been noted following the use of the anti-CD52 monoclonal antibody alemtuzumab for in vivo TCD. ${ }^{21}$ Burns et al. demonstrated a 48\% incidence of EBV reactivation and 4.3\% EBV PLTD in consecutive alloHSCT recipients receiving a total of 50mg of alemtuzumab during conditioning. ${ }^{21}$

\section{Strategies to prevent EBV PTLD}

There are currently no effective antiviral agents against EBV. Therefore, prevention or preemptive therapy is vital in reducing morbidity/mortality caused by EBV PLTD. Recent evidence-based guidelines from the European Conference in Infections in Leukemia (ECIL) recommend weekly screening of EBV DNA for at least three months in high-risk allogeneic HSCT recipients. ${ }^{1}$ Monitoring of EBV viral load using quantitative NAT assay, usually by polymerase chain reaction (PCR) amplification assays is recommended. When EBV DNA is detected to a certain threshold, reduction of immunosuppression and pre-emptive treatment with rituximab is recommended. ${ }^{1}$ However, with heterogeneity in the assays used for assessing EBV viral load, recommendations for intervention vary. Other novel emerging strategies include prophylactic rituximab with alloHSCT conditioning chemotherapy or the use of EBV CTLs. ${ }^{1}$

\section{Measurement of EBV DNA biomarkers}

With different assays using serum, whole blood (WB), or peripheral blood mononuclear cells (PBMCs) to measure EBV DNA, results are difficult to generalise and require differing 
interpretation. With no universal standard for PCR assays, the ECIL guidelines do not recommend a specific threshold value of EBV viremia for initiating pre-emptive therapy. Studies have defined an EBV threshold of 1,000copies/mL, 10,000copies/mL, or 40,000copies/mL when determined in plasma, whole blood, or serum, respectively. ${ }^{1}$ The rate of increase of EBV copies is also clinically significant given that increases in EBV viremia are due to the expansion of EBV-infected memory B-cells in the peripheral blood.

A recently study that used receiver operating characteristic (ROC) curves to predict PTLD among 2642 European recipients of both solid organ and alloHSCT transplants was able to develop a model to predict the development of EBV viremia measured in plasma. ${ }^{22} \mathrm{EBV}$ viremia was observed in 331/1784 recipients (18.6\%, 95\% CI 16.8-20.4). The area under the curve (AUC) of the ROC for EBV viremia predicting the development of PTLD was 59\% (5168\%) amongst alloHSCT recipients. Recipients with a negative EBV DNA were less likely to develop PTLD [0.09 (0.05-0.16)] compared to those with EBV DNA at the lower limit of detection. Those with an EBV DNA of 501-5,000copies/mL had a non-significant increased risk of PTLD [2.03 (0.83-4.95)] while a viral load >5,000copies/mL was significantly associated with PTLD [5.78 (1.57-21.25)]. The inclusion of clinical predictors such as age, gender, transplant year and type, high-risk EBV serostatus, and routine biochemistry in addition to EBV viremia in the ROC model increased AUC to 84\% (79-89\%) among HSCT. Additional factors such as TCD treatment, acute GVHD and donor match increased AUC to 85\% (78-91\%). These results demonstrate that there is little benefit for the routine monitoring of all alloHSCT recipients, but rather only those with risk factors such as TCD treatment (including the use of ATG or alemtuzumab), acute GVHD and a mismatched donor. 
Additionally, it was shown that a plasma viral load $>5,000$ copies/mL significantly increased the risk of developing EBV PTLD. This must be taken into consideration for the timing of initiating pre-emptive treatment, with early intervention required prior to the EBV DNA threshold of 5,000copies/mL.

For detection of EBV, the optimal choice of assay sample between plasma, WB and PBMCs, is debatable. ${ }^{23,24}$ Despite partial correlation between WB and PBMC $(\mathrm{r}=0.755, \mathrm{P}<$ 0.001), ${ }^{25}$ detection with PBMCs appears to be the most sensitive technique, however this technique may be too sensitive for indicating the onset of a rising EBV level as a surrogate to predict PTLD. ${ }^{26}$ It has also been suggested that, by using serum, the cell-free viral DNA detected may reflect either the release of EBV material due to cell lysis or a lytic infection, which may be more closely associated with the onset of PTLD. ${ }^{25,27,28}$ Care must also be taken when interpreting results due to a wide inter-laboratory variation in results, however the standardization and reproducibility of these results are improving. ${ }^{29,30}$ Because of such variation in assays sample types used and DNA levels reported in the literature, it is difficult to assess the exact DNA levels required for preventative management interventions.

\section{Pre-emptive therapy with rituximab}

The two most common pre-emptive strategies associated with a reduction in progression to PTLD after EBV viremia are treatment with rituximab and reduction of immunosuppression. ${ }^{1}$ The ECIL guideline recommends that the primary method for pre-emptive therapy is rituximab, $375 \mathrm{mg} / \mathrm{m}^{2}$, once weekly until EBV viremia negativity. ${ }^{1}$ The number of doses administered should be assessed locally on the basis of changes in EBV viremia and an assessment of the patient's immune function; this usually ranges from one to four doses. In addition, the use of 
rituximab should be combined with reduction in immunosuppression if possible, particularly as there is a significant survival advantage in patients who have progressed to PTLD when both rituximab therapy and a reduction of immunosuppression are applied (39\% cumulative incidence of PTLD related mortality for rituximab alone, compared to $16 \%$ with combined rituximab and reduction in immunosuppression). ${ }^{3}$ The utility of pre-emptive therapy with rituximab is well established, with a rate of cure or EBV negativity using this method of $90 \%$, versus using rituximab for the treatment of PTLD at $63 \% .{ }^{31}$ The optimal EBV viral load threshold to initiate pre-emptive therapy is currently unknown, though various studies have used EBV viral loads thresholds as low as 1,000copies/mL (plasma) to 40,000copies/mL (WB). A summary of studies which describes a pre-emptive approach is shown in Table 2.

A recent publication from Jain et al. evaluating 488 patients who underwent myeloablative or non-myeloablative alloHSCT's described the use of pre-emptive rituximab in one of the largest cohorts to date. ${ }^{32,33}$ The institutional protocol for initiation of rituximab was EBV measured on WB >2,000copies/ml with increasing viral load (clinically relevant EBV reactivation); alternatively, if EBV copy number was $>5,000$ copies/mL, immediate therapy was considered with repeat monitoring after 3-5 days; alternatively, for patients with $<5,000$ copies/mL, repeated EBV testing every 3-5 days with treatment instituted in patients considered at a higher risk for EBV reactivation. Rituximab was given at $375 \mathrm{mg} / \mathrm{m}^{2}$ weekly until EBV levels were undetectable or at provider's discretion. Sixty-seven (14\%) patients had clinically relevant EBV reactivation after alloHSCT. Of these, 60 (90\%) received rituximab for EBV reactivation which resolved without any additional clinical consequence, 1 (1.5\%) received rituximab but later developed PTLD and 6 (9\%) developed PTLD prior to initiation 
of rituximab. Median time to EBV reactivation was at 34 days (range, 13-602) post alloHSCT. Levels of EBV copies/mL at the time of initiation of rituximab were 2,000-3,999 in 14 (23\%), 4,000-5,999 in 11 (18\%), 6,000-7,999 in $3(5 \%)$ and $\geq 8,000$ in 32 (53\%) patients. The median of the highest level of EBV load was 10,300copies/ml (range, 2,000-645,000). Doses of rituximab required to clear viremia were 1 in 31 (53\%), 2 in 15 (26\%), 3 in 5 (9\%) and 4 in 7 (12\%) patients. It took a median of nine days (range, 1-41) from the initiation of rituximab to resolve viremia. The median level of EBV viral load in blood was higher in patients who required more than one dose of rituximab (1 dose: 8,060copies/mL; >1 dose: 13,100copies/mL; $\mathrm{P}=0.03)$. Immunosuppression was reduced in 15 (47\%) patients whose viremia cleared with one dose of rituximab compared to 4 (15\%) patients who required $>1$ dose to clear $(\mathrm{P}=0.005)$. This finding suggests early intervention may reduce the total cumulative dose of rituximab required to pre-emptively treat the EBV reactivation. Whilst the pre-emptive strategy used by Jain et al. of treating with rituximab when EBV DNA level on WB was between 2,0005,000copies/mL did result in a small number of break-through PTLDs, $1.4 \%$ is among the lowest rate demonstrated by a large-scale study to date. The low rate of PTLD in this study is particularly remarkable given that over half of the study cohort had received ATG.

A similar strategy was reported by Michallet et al. who evaluated 359 allo-HSCTs using EBV PCR monitoring on $\mathrm{WB}^{34}$ When a patient exceeded $1,000 \mathrm{copies} / \mathrm{ml}$, the primary therapeutic intervention was a gradual weaning of immunosuppression, and then rituximab infusions $\left(375 \mathrm{mg} / \mathrm{m}^{2}\right.$, four injections weekly) were administered when the viremia exceeded 10,000copies/ml. Two hundred and twenty-two (62\%) patients reactivated EBV after a median time of 1.3 months (0.7-2.5) after allo-HSCT with a cumulative incidence of $48 \%$ (47-50) at 
3 months. Among the 222 patients with EBV reactivation, only 35 (15.7\%) needed treatment with rituximab. Rituximab was introduced after a median time of 55 days post transplantation with a median number of five infusions and a median dose of $2025 \mathrm{mg} / \mathrm{m}^{2}$. EBV treatment was successful in all patients; none progressed to PTLD. Interestingly, this study also demonstrated that the presence of EBV reactivation (with multivariate analysis) was associated with a significant lower relapse rate, $\mathrm{HR}=0.52[0.35-1], \mathrm{P}=0.05$ on multivariate analysis . This preemptive strategy used by Michallet et al. was successful in preventing PTLD and provides a useful technique of defining an early EBV DNA level on WB to reduce immune suppression. However, the results are difficult to extrapolate to other studies as the ATG usage rate and dose is not reported and therefore the patients' baseline risk of developing PTLD may not be the same as other studies.

Other novel approaches in pre-emptive treatment involve treating only when EBV load is $>40,000$ copies $/ \mathrm{mL}$ (WB) and circulating CD4+ T-cells $<0.3 \times 10^{9} / \mathrm{L},{ }^{35}$ or when the first signs of clinical symptoms of PTLD (eg, adenopathy or fever) appeared, in addition to $>4,000$ copies/ $\mu \mathrm{g}(\mathrm{PBMC})^{16}$. However, these strategies were associated with the development of PTLD and required more intensive patient monitoring than the more conservative EBV viral load monitoring. By using the latter method, Wagner et al. demonstrated that the detection of 2 or more levels of EBV DNA levels $>4,000$ copies/ $\mu$ g (PBMC) had a sensitivity of $100 \%$ for the prediction of early PTLD but a specificity of only 50\% (in 8/16 patients). ${ }^{16}$ Despite initial concerns about the safety of rituximab following alloHSCT, the impact of pre-emptive rituximab has been consistently shown to have no significant deleterious effect on overall survival or non-relapse mortality. ${ }^{21}$ 
Jain et al. showed that when using pre-emptive management with rituximab, patients who demonstrate a higher level of EBV viremia before rituximab intervention, required a greater number of subsequent doses of rituximab to clear EBV viremia. ${ }^{32}$ As it has been demonstrated that the majority of patients who exceed EBV viral loads of 5,000copies/mL will also reach 10,000 copies/mL (serum), ${ }^{28}$ it is hypothesised that pre-emptive treatment with rituximab at a lower threshold, may reduce the treatment required to clear viremia and be advantageous both economically and for the patients' quality of life.

\section{Prophylactic therapy with rituximab}

Given the apparent safety and efficacy of rituximab administered post alloHSCT for EBV viremia, as well as previous studies suggesting that rituximab administered prior to alloHSCT for B-cell malignancy lowered the incidence of EBV reactivation post-transplant, ${ }^{21}$ some investigators have assessed the role of rituximab prophylaxis either immediately before, or after the day of stem cell infusion. ${ }^{36-39}$ Studies using rituximab prophylactically are outlined in Table 2.

Dominietto et al. used a 200mg total dose of rituximab on day +5 in 55 alloHSCT patients compared to a control group of 68 patients without rituximab, which resulted in a significantly lower rate of EBV viremia [31/55 (56\%) vs 58/68 (85\%), $\mathrm{P}=0.0004]$ and a significantly lower risk of exceeding 1,000copies/105 (PBMC) [8/55 (14\%) vs 33/68 (49\%), $\mathrm{P}=0.0001]$. There were no patients in the rituximab prophylaxis group who died following the development of PTLD vs 2/68 (3\%) in the control group ( $\mathrm{P}=0.3)$. Additionally, the cumulative incidence of grade II-IV acute GvHD was significantly reduced in those receiving rituximab 
(20 vs 38\%, $\mathrm{P}=0.02$ ). There was a trend for a survival advantage for patients receiving rituximab prophylaxis (46 vs $40 \%, \mathrm{P}=0.1$ ), mainly because of lower transplant related mortality (25 vs 37\%, $\mathrm{P}=0.1$ ). With all patients in this study considered at high risk of EBV PTLD due to ATG use, the approach used by Dominietto et al. is particularly attractive because it may result in a reduced requirement for monitoring and follow-up, which can be difficult for some patients. However, with $14 \%$ of patients still requiring a pre-emptive dose of rituximab with EBV DNA $>1,000 / 10^{5}$ cells on PBMC, some degree of monitoring is still required.

In the setting of haploidentical alloHSCT, Peccatori et al. administered a single 500mg rituximab dose on day -1 in 121 patients in combination with sirolimus for GVHD prophylaxis. No cases of PTLD or "high-titer" EBV viremia were documented, although the definition of this EBV level was not reported. The authors comment that this result was may have been due to the combined effect of rapid T-cell recovery and the inclusion of rituximab in the conditioning regimen. In addition, sirolimus may have contributed to the reduction in EBV viremia, as it has been previously demonstrated to inhibit the of growth of human EBVtransformed B-lymphocytes in vitro with reports of its use in combination with rituximab to prevent EBV viremia successfully in renal transplantation. ${ }^{40,41}$

Van Besien et al. administered a single dose of rituximab $375 \mathrm{mg} / \mathrm{m}^{2}$ two weeks prior to haplo-cord alloHSCT unless the patient has a recent prior exposure to rituximab due to treatment for a primary B-cell malignancy. When this cohort was compared to a control group without prior rituximab exposure, EBV reactivation occurred in 1/51 (2\%) with rituximab exposure vs 27/146 (18\%) without prior rituximab exposure ( $\mathrm{P}=0.004)$. PTLD developed in 16/146 (12\%) without prior rituximab exposure vs 0/51 with rituximab exposure. This study 
suggests that the routine use of rituximab post transplant can prevent EBV PTLD, as well as suggesting that prior rituximab within 6 months of HSCT can lower the risk of developing EBV PTLD and might be used to help inform risk stratification.

\section{Prophylaxis or pre-emptive therapy with CTLs}

Another novel strategy for the prevention of EBV PTLD is the use of donor or third party EBVspecific CTLs. The utility of CTLs has been demonstrated both in the pre-emptive setting, with approximately 95\% successful elimination of EBV viremia, and in the treatment of PTLD, with $65 \%-88 \%$ success, even after the failure of rituximab based therapy. ${ }^{31,42-46}$. However access to these products and the requirement for HLA matching poses a challenge. ${ }^{1}$ Heslop et al. report on the largest cohort receiving CTLs for prophylaxis for EBV PTLD with 101 alloHSCT in which $90 \%$ were CD6+ and CD8+T-cell-depleted allografts. ${ }^{46}$ The majority of patients received a single dose of $2 \times 10^{7}$ cells $/ \mathrm{m}^{2}$ EBV-specific CTLs followed by weekly EBV monitoring. Of these, 12/101(12\%) patients developed elevated levels of EBV DNA, though the exact viral load was not reported. Prophylactic infusions decreased the EBV load in 11/12 patients, with no other evidence of EBV PTLD before infusion. In the one exception, EBV DNA remained elevated at more than 1,500copies/ $\mu$ g (PBMC) for more than a year despite an additional dose of CTLs, but then normalized without the development of PTLD. The authors commented that these results, compared to 42 patients who did not receive CTLs but who were enrolled on the same transplantation protocol, were superior in preventing PTLD with an incidence of 5/42 (11\%) in the group who did not receive CTLs.

Evidence for EBV PTLD management with the use of EBV CTLs is also a rapidly expanding area, with a number clinical trials emerging in recent years, including a large phase 
III study evaluating the use of commercially available EBV CTL in alloHSCT (MATCH) ${ }^{47}$ as well as a number of phase I studies completed or in progress. ${ }^{44,48}$

\section{Potential future strategies}

Peccatori et al., demonstrated that sirolimus, a macrolide antifungal antibiotic isolated from Streptomyces hygroscopicus, may have a beneficial effect against EBV viremia and PTLD. ${ }^{38}$ The mechanism of action for this effect has previously been described, with sirolimus not only demonstrating inhibitory effects on normal cells of the immune system, but also inhibiting the proliferation of transformed cell lines. ${ }^{49}$ Experimental studies have demonstrated inhibition of growth of human EBV-transformed B lymphocytes by sirolomus, including an inhibitory effect on the growth of PTLD-like EBV cells xenotransplanted into severe combined immunodeficiency mice, with cell death via apoptosis induction. ${ }^{40,50}$ Potential mechanisms underlying the inhibitory effect of sirolimus include: i) inhibition of IL-10 production, an autocrine growth factor for EBV+ B-cell lymphomas, ii) inhibition of constitutive activation of the Janus kinase/signal transducer and activator of transcription pathway and iii) direct effects on the expression of cell-cycle proteins, potentially inducing arrest of EBV+ B-cell lymphomas in the G1 phase. $^{40}$ Reddy et al. have proposed that a combination of low-dose rituximab (100-150 mg/m²) and sirolimus GVHD prophylaxis (with other immunosuppressive agents) may be the optimal EBV PTLD management strategy to significantly reduce the expense, morbidity, and mortality in high-risk populations, however the use of this regime has not yet been reported.

This article is protected by copyright. All rights reserved. 
T-cell manipulation with post-transplant cyclophosphamide (PTCy) may also be a potential strategy to prevent EBV PTLD. A large retrospective analysis of PTLD incidence in 785 adult alloHSCT recipients given PTCy as GVHD prophylaxis demonstrated no PTLD at 1 year post HSCT. ${ }^{51}$ This finding is consistent with recent reports on the use of PTCy in haploidentical HSCT. ${ }^{52,53}$ Several hypotheses for this effect have been described including destruction of donor and host EBV-infected B-cells, relative sparing of EBV specific memory T-cells, and rapid immune reconstitution. ${ }^{51}$ Recent studies describing dual $\mathrm{T}$ lymphocyte suppression with ATG and PTCy in haploidentical transplantation however, have demonstrated a significant EBV PTLD risk, with 64\% reactivating EBV and 8\% developing PTLD, although all patients were successfully treated with rituximab and reduction in immune suppression. ${ }^{54}$

\section{Conclusions}

EBV PTLD prevention is an essential component of care in the post alloHSCT setting, especially in T-cell depleted allograft settings. The most commonly used strategies have utilized weekly EBV PCR monitoring, usually by quantifying viral load in plasma or WB. Due to the lack of standardization of assays and sample types used, it is difficult to assess the exact DNA level required for preventative management interventions and therefore pre-emptive rituximab should be administered depending on an institute-specific threshold.

Determination of an institute-specific threshold needs to take account of sensitivity and specificity of the assay used as well as the turn-around time of results. However, in studies where the lowest incidences of PTLD have been reported, thresholds for initiating treatment have been 1,000copies/mL using plasma or 2,000-10,000copies/mL using WB. This review 
suggests that the optimal PTLD prevention strategy in alloHSCT recipients who been offered T-cell-depleting treatments (including the use of ATG or alemtuzumab) for GVHD prophylaxis, have developed acute GVHD or have been transplanted using a mismatched donor is, i) monitoring of EBV DNA weekly post-transplant until day +100 using plasma or WB as analyte and, ii) pre-emptively reducing immune suppression (if possible) at an EBV DNA of $>1,000$ copies $/ \mathrm{mL}$ (plasma or WB), and at a threshold of $>1000$ copies $/ \mathrm{mL}$ (plasma) or $>5,000$ copies $/ \mathrm{mL}$ (WB), treating with rituximab $375 \mathrm{mg} / \mathrm{m}^{2}$ weekly until clearance of EBV DNA. Although the body of evidence is still growing, prophylactic rituximab appears to be a feasible and safe strategy, particularly if pre-emptive monitoring is problematic. Future management strategies such as prophylactic EBV specific CTLs have shown promising results and as this procedure becomes less expensive and more accessible, it may become the strategy of choice for EBV PTLD prevention. 


\section{References}

1. Styczynski J, van der Velden W, Fox CP, et al. Management of Epstein-Barr Virus infections and posttransplant lymphoproliferative disorders in patients after allogeneic hematopoietic stem cell transplantation: Sixth European Conference on Infections in Leukemia (ECIL-6) guidelines. Haematologica. 2016;101(7):803-811.

2. Curtis RE, Travis LB, Rowlings PA, et al. Risk of lymphoproliferative disorders after bone marrow transplantation: a multi-institutional study. Blood. 1999;94(7):2208-2216.

3. Styczynski J, Gil L, Tridello G, et al. Response to rituximab-based therapy and risk factor analysis in Epstein Barr Virus-related lymphoproliferative disorder after hematopoietic stem cell transplant in children and adults: a study from the Infectious Diseases Working Party of the European Group for Blood and Marrow Transplantation. Clin Infect Dis. 2013;57(6):794-802.

4. Naik S, Riches M, Hari P, et al. Survival outcomes of allogeneic hematopoietic cell transplants with EBV-positive or EBV-negative post-transplant lymphoproliferative disorder, A CIBMTR study. Transpl Infect Dis. 2019:e13145.

5. Styczynski J, Reusser P, Einsele H, et al. Management of HSV, VZV and EBV infections in patients with hematological malignancies and after SCT: guidelines from the Second European Conference on Infections in Leukemia. Bone Marrow Transplant. 2009;43(10):757-770.

6. Dierickx D, Tousseyn T, Gheysens O. How I treat posttransplant lymphoproliferative disorders. Blood. 2015;126(20):2274-2283.

7. Walker I, Panzarella T, Couban S, et al. Pretreatment with anti-thymocyte globulin versus no antithymocyte globulin in patients with haematological malignancies undergoing haemopoietic cell transplantation from unrelated donors: a randomised, controlled, open-label, phase 3, multicentre trial. Lancet Oncol. 2016;17(2):164-173.

8. Brunstein CG, Weisdorf DJ, DeFor T, et al. Marked increased risk of Epstein-Barr virus-related complications with the addition of antithymocyte globulin to a nonmyeloablative conditioning prior to unrelated umbilical cord blood transplantation. Blood. 2006;108(8):2874-2880.

9. Fox CP, Burns D, Parker AN, et al. EBV-associated post-transplant lymphoproliferative disorder following in vivo T-cell-depleted allogeneic transplantation: clinical features, viral load correlates and prognostic factors in the rituximab era. Bone Marrow Transplant. 2014;49(2):280-286.

10. Mensen A, Na IK, Hafer R, et al. Comparison of different rabbit ATG preparation effects on early lymphocyte subset recovery after allogeneic HSCT and its association with EBV-mediated PTLD. $J$ Cancer Res Clin Oncol. 2014;140(11):1971-1980.

11. Kimura H, Ito Y, Suzuki R, Nishiyama Y. Measuring Epstein-Barr virus (EBV) load: the significance and application for each EBV-associated disease. Rev Med Virol. 2008;18(5):305-319.

12. Heslop HE. How I treat EBV lymphoproliferation. Blood. 2009;114(19):4002-4008.

13. Hislop AD, Taylor GS, Sauce D, Rickinson AB. Cellular responses to viral infection in humans: lessons from Epstein-Barr virus. Annu Rev Immunol. 2007;25:587-617.

14. Sabattini E, Bacci F, Sagramoso C, Pileri SA. WHO classification of tumours of haematopoietic and lymphoid tissues in 2008: an overview. Pathologica. 2010;102(3):83-87.

15. van Esser JW, van der Holt B, Meijer E, et al. Epstein-Barr virus (EBV) reactivation is a frequent event after allogeneic stem cell transplantation (SCT) and quantitatively predicts EBV-lymphoproliferative disease following T-cell--depleted SCT. Blood. 2001;98(4):972-978.

16. Wagner $\mathrm{HJ}$, Cheng $\mathrm{YC}$, Huls $\mathrm{MH}$, et al. Prompt versus preemptive intervention for EBV lymphoproliferative disease. Blood. 2004;103(10):3979-3981.

17. Baron F, Mohty M, Blaise D, et al. Anti-thymocyte globulin as graft-versus-host disease prevention in the setting of allogeneic peripheral blood stem cell transplantation: a review from the Acute Leukemia Working Party of the European Society for Blood and Marrow Transplantation. Haematologica. 2017;102(2):224-234.

18. Kekre N, Antin JH. ATG in allogeneic stem cell transplantation: standard of care in 2017? Counterpoint. Blood Adv. 2017;1(9):573-576. 
19. Kroger N, Solano C, Wolschke C, et al. Antilymphocyte Globulin for Prevention of Chronic Graftversus-Host Disease. N Engl J Med. 2016;374(1):43-53.

20. Finke J, Bethge WA, Schmoor C, et al. Standard graft-versus-host disease prophylaxis with or without anti-T-cell globulin in haematopoietic cell transplantation from matched unrelated donors: a randomised, open-label, multicentre phase 3 trial. Lancet Oncol. 2009;10(9):855-864.

21. Burns DM, Rana S, Martin E, et al. Greatly reduced risk of EBV reactivation in rituximab-experienced recipients of alemtuzumab-conditioned allogeneic HSCT. Bone Marrow Transplant. 2016;51(6):825832.

22. Wareham NE, Mocroft A, Sengelov H, et al. The value of EBV DNA in early detection of post-transplant lymphoproliferative disorders among solid organ and hematopoietic stem cell transplant recipients. $J$ Cancer Res Clin Oncol. 2018;144(8):1569-1580.

23. Ruf S, Behnke-Hall K, Gruhn B, et al. Comparison of six different specimen types for Epstein-Barr viral load quantification in peripheral blood of pediatric patients after heart transplantation or after allogeneic hematopoietic stem cell transplantation. J Clin Virol. 2012;53(3):186-194.

24. Wagner HJ, Wessel $\mathrm{M}$, Jabs $\mathrm{W}$, et al. Patients at risk for development of posttransplant lymphoproliferative disorder: plasma versus peripheral blood mononuclear cells as material for quantification of Epstein-Barr viral load by using real-time quantitative polymerase chain reaction. Transplantation. 2001;72(6):1012-1019.

25. Chiereghin A, Prete A, Belotti T, et al. Prospective Epstein-Barr virus-related post-transplant lymphoproliferative disorder prevention program in pediatric allogeneic hematopoietic stem cell transplant: virological monitoring and first-line treatment. Transpl Infect Dis. 2016;18(1):44-54.

26. Preiksaitis JK, Pang XL, Fox JD, et al. Interlaboratory comparison of epstein-barr virus viral load assays. Am J Transplant. 2009;9(2):269-279.

27. Kroll J, Li S, Levi M, Weinberg A. Lytic and latent EBV gene expression in transplant recipients with and without post-transplant lymphoproliferative disorder. J Clin Virol. 2011;52(3):231-235.

28. Raberahona M, Wackenheim C, Germi R, et al. Dynamics of Epstein-Barr viral load after hematopoietic stem cell transplantation and effect of preemptive rituximab therapy. Transpl Infect Dis. 2016;18(6):889895.

29. Hayden RT, Hokanson KM, Pounds SB, et al. Multicenter comparison of different real-time PCR assays for quantitative detection of Epstein-Barr virus. J Clin Microbiol. 2008;46(1):157-163.

30. Germi R, Lupo J, Semenova T, et al. Comparison of commercial extraction systems and PCR assays for quantification of Epstein-Barr virus DNA load in whole blood. J Clin Microbiol. 2012;50(4):1384-1389.

31. Styczynski J, Einsele H, Gil L, Ljungman P. Outcome of treatment of Epstein-Barr virus-related posttransplant lymphoproliferative disorder in hematopoietic stem cell recipients: a comprehensive review of reported cases. Transpl Infect Dis. 2009;11(5):383-392.

32. Jain T, Kosiorek HE, Grys TE, et al. Single dose versus multiple doses of rituximab for preemptive therapy of Epstein-Barr virus reactivation after hematopoietic cell transplantation. Leuk Lymphoma. 2019;60(1):110-117.

33. Jain T, Kung ST, Kosiorek H, et al. Outcomes with Pre-Emptive Rituximab (pre-R) Treatment for Epstein-Barr Viremia (EBV) after Allogeneic Hematopoietic Stem Cell Transplantation (HCT). Biology of Blood and Marrow Transplantation. 2017;23(3):S279-S280.

34. Michallet M, Sobh M, Ranchon F, et al. Epstein-Barr Virus (EBV) Reactivation, Its Treatment with Rituximab and Their Impact on Relapse after Allogeneic Hematopoietic Stem Cell Transplantation for Hematological Malignancies. Blood. 2016;128(22):3695-3695.

35. Worth A, Conyers R, Cohen J, et al. Pre-emptive rituximab based on viraemia and T cell reconstitution: a highly effective strategy for the prevention of Epstein-Barr virus-associated lymphoproliferative disease following stem cell transplantation. Br J Haematol. 2011;155(3):377-385.

36. Bacigalupo A, Dominietto A, Soracco M, et al. Rituximab Prophylaxis of EBV Reactivation after Alternative Donor Transplants Following Anti-Thymocyte Globulin-Based Conditioning Regimens. Blood. 2008;112(2232).

37. Dominietto A, Tedone E, Soracco M, et al. In vivo B-cell depletion with rituximab for alternative donor hemopoietic SCT. Bone Marrow Transplant. 2012;47(1):101-106. 
38. Peccatori J, Forcina A, Clerici D, et al. Sirolimus-based graft-versus-host disease prophylaxis promotes the in vivo expansion of regulatory $T$ cells and permits peripheral blood stem cell transplantation from haploidentical donors. Leukemia. 2015;29(2):396-405.

39. Van Besien K, Bachier-Rodriguez L, Satlin M, et al. Prophylactic rituximab prevents EBV PTLD in haplo-cord transplant recipients at high risk. Leuk Lymphoma. 2019;60(7):1693-1696.

40. Krams SM, Martinez OM. Epstein-Barr virus, rapamycin, and host immune responses. Curr Opin Organ Transplant. 2008;13(6):563-568.

41. Garcia VD, Bonamigo Filho JL, Neumann J, et al. Rituximab in association with rapamycin for posttransplant lymphoproliferative disease treatment. Transpl Int. 2003;16(3):202-206.

42. Barker JN, Doubrovina E, Sauter C, et al. Successful treatment of EBV-associated posttransplantation lymphoma after cord blood transplantation using third-party EBV-specific cytotoxic T lymphocytes. Blood. 2010;116(23):5045-5049.

43. Moosmann A, Bigalke I, Tischer J, et al. Effective and long-term control of EBV PTLD after transfer of peptide-selected T cells. Blood. 2010;115(14):2960-2970.

44. Doubrovina E, Oflaz-Sozmen B, Prockop SE, et al. Adoptive immunotherapy with unselected or EBVspecific T cells for biopsy-proven EBV+ lymphomas after allogeneic hematopoietic cell transplantation. Blood. 2012;119(11):2644-2656.

45. Leen AM, Bollard CM, Mendizabal AM, et al. Multicenter study of banked third-party virus-specific T cells to treat severe viral infections after hematopoietic stem cell transplantation. Blood. 2013;121(26):5113-5123.

46. Heslop HE, Slobod KS, Pule MA, et al. Long-term outcome of EBV-specific T-cell infusions to prevent or treat EBV-related lymphoproliferative disease in transplant recipients. Blood. 2010;115(5):925-935.

47. NIH U.S. National Library of Medicine. Tabelecleucel for Allogeneic Hematopoietic Cell Transplant Subjects With Epstein-Barr Virus-Associated Post-Transplant Lymphoproliferative Disease (EBV+ PTLD) After Failure of Rituximab (MATCH). 2019; clinicaltrials.gov. Accessed 11/10/2019.

48. Withers B, Blyth E, Clancy LE, et al. Long-term control of recurrent or refractory viral infections after allogeneic HSCT with third-party virus-specific T cells. Blood Adv. 2017;1(24):2193-2205.

49. Reddy N, Rezvani K, Barrett AJ, Savani BN. Strategies to prevent EBV reactivation and posttransplant lymphoproliferative disorders (PTLD) after allogeneic stem cell transplantation in high-risk patients. Biol Blood Marrow Transplant. 2011;17(5):591-597.

50. Majewski M, Korecka M, Kossev P, et al. The immunosuppressive macrolide RAD inhibits growth of human Epstein-Barr virus-transformed B lymphocytes in vitro and in vivo: A potential approach to prevention and treatment of posttransplant lymphoproliferative disorders. Proc Natl Acad Sci U S A. 2000;97(8):4285-4290.

51. Kanakry JA, Kasamon YL, Bolanos-Meade J, et al. Absence of post-transplantation lymphoproliferative disorder after allogeneic blood or marrow transplantation using post-transplantation cyclophosphamide as graft-versus-host disease prophylaxis. Biol Blood Marrow Transplant. 2013;19(10):1514-1517.

52. Raiola AM, Dominietto A, Ghiso A, et al. Unmanipulated haploidentical bone marrow transplantation and posttransplantation cyclophosphamide for hematologic malignancies after myeloablative conditioning. Biol Blood Marrow Transplant. 2013;19(1):117-122.

53. Solomon SR, Sizemore CA, Sanacore M, et al. Haploidentical transplantation using T cell replete peripheral blood stem cells and myeloablative conditioning in patients with high-risk hematologic malignancies who lack conventional donors is well tolerated and produces excellent relapse-free survival: results of a prospective phase II trial. Biol Blood Marrow Transplant. 2012;18(12):1859-1866.

54. Law AD, Salas MQ, Lam W, et al. Reduced-Intensity Conditioning and Dual T Lymphocyte Suppression with Antithymocyte Globulin and Post-Transplant Cyclophosphamide as Graft-versus-Host Disease Prophylaxis in Haploidentical Hematopoietic Stem Cell Transplants for Hematological Malignancies. Biol Blood Marrow Transplant. 2018;24(11):2259-2264.

55. Landgren O, Gilbert ES, Rizzo JD, et al. Risk factors for lymphoproliferative disorders after allogeneic hematopoietic cell transplantation. Blood. 2009;113(20):4992-5001.

56. Uhlin M, Wikell H, Sundin M, et al. Risk factors for Epstein-Barr virus-related post-transplant lymphoproliferative disease after allogeneic hematopoietic stem cell transplantation. Haematologica. 2014;99(2):346-352. 
57. Chakrabarti S, Milligan DW, Pillay D, et al. Reconstitution of the Epstein-Barr virus-specific cytotoxic T-lymphocyte response following T-cell-depleted myeloablative and nonmyeloablative allogeneic stem cell transplantation. Blood. 2003;102(3):839-842.

58. Patriarca F, Medeot M, Isola M, et al. Prognostic factors and outcome of Epstein-Barr virus DNAemia in high-risk recipients of allogeneic stem cell transplantation treated with preemptive rituximab. Transpl Infect Dis. 2013;15(3):259-267.

59. van Esser JW, Niesters HG, van der Holt B, et al. Prevention of Epstein-Barr virus-lymphoproliferative disease by molecular monitoring and preemptive rituximab in high-risk patients after allogeneic stem cell transplantation. Blood. 2002;99(12):4364-4369.

60. Deeg HJ, Storer BE, Boeckh M, et al. Reduced incidence of acute and chronic graft-versus-host disease with the addition of thymoglobulin to a targeted busulfan/cyclophosphamide regimen. Biol Blood Marrow Transplant. 2006;12(5):573-584.

61. Carpenter B, Haque T, Dimopoulou M, et al. Incidence and dynamics of Epstein-Barr virus reactivation after alemtuzumab-based conditioning for allogeneic hematopoietic stem-cell transplantation. Transplantation. 2010;90(5):564-570.

62. Wang Y, Fu HX, Liu DH, et al. Influence of two different doses of antithymocyte globulin in patients with standard-risk disease following haploidentical transplantation: a randomized trial. Bone Marrow Transplant. 2014;49(3):426-433.

\section{Conflict of Interest: None}


Table 1. Risk factors for EBV PTLD in HSCT

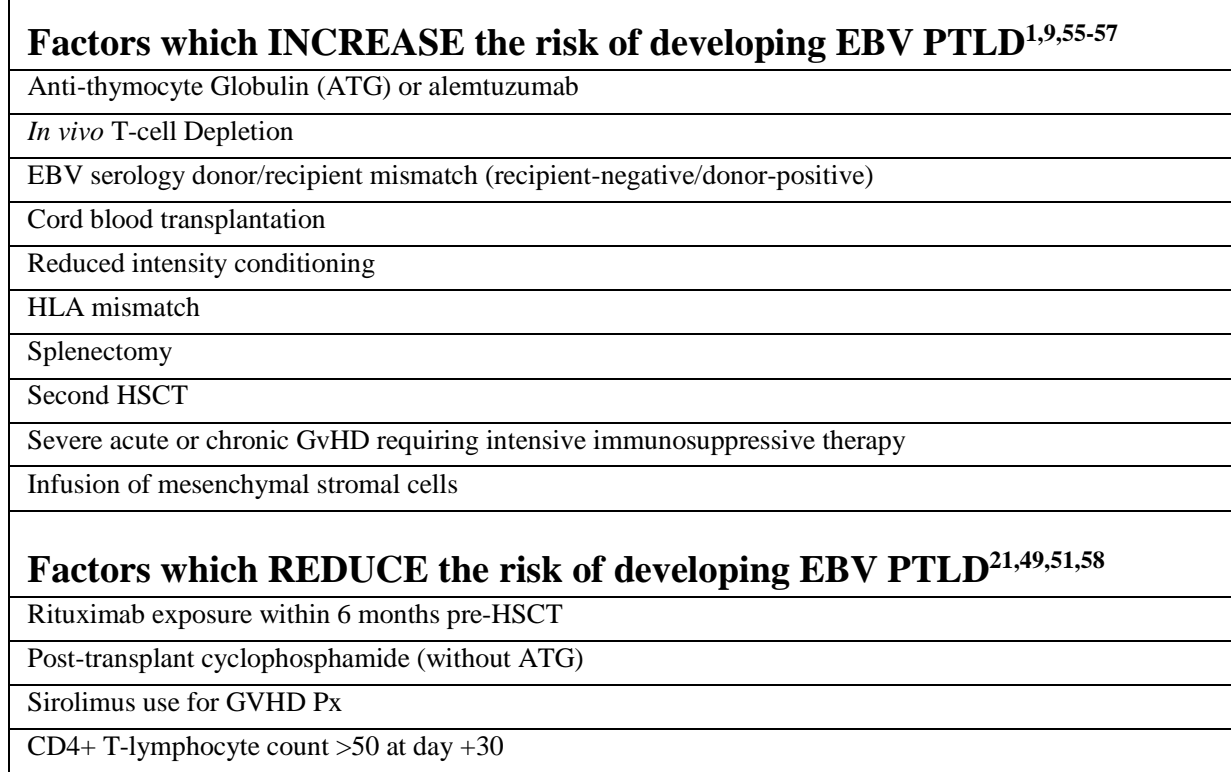


Table 2. Summary of reported EBV preventative strategies

\begin{tabular}{|c|c|c|c|c|c|c|c|}
\hline Reference & $\begin{array}{l}\text { Patients and HSCT } \\
\text { Protocol }\end{array}$ & $\begin{array}{l}\text { EBV } \\
\text { Monitoring }\end{array}$ & $\begin{array}{l}\text { Sample } \\
\text { used }\end{array}$ & $\begin{array}{l}\text { Pre-emptive } \\
\text { EBV } \\
\text { threshold }\end{array}$ & Treatment & $\begin{array}{l}\text { EBV reactivation } \\
\text { and PTLD rates }\end{array}$ & Other outcomes \\
\hline \multicolumn{8}{|c|}{ Pre-emptive therapy with rituximab } \\
\hline $\begin{array}{l}\text { Van Esser et } \\
\text { al. } 2002^{59}\end{array}$ & $\begin{array}{l}\mathrm{N}=49 \\
\text { Conditioning = CyTBI } \\
\text { GVHD Px = CSP, TCD } \\
\text { ATG 10mg/kg (Imtix } \\
\text { Sangstat, Amstelveen, The } \\
\text { Netherlands), with partial } \\
\text { ex-vivo T-cell depletion }\end{array}$ & $\begin{array}{l}\text { Weekly until day } \\
180 \text { or longer in } \\
\text { patients with chronic } \\
\text { graft-versus-host } \\
\text { disease (GVHD) }\end{array}$ & Plasma & $>1,000$ geq $/ \mathrm{mL}$ & $\begin{array}{l}\text { Pre-emptive rituximab } \\
375 \mathrm{mg} / \mathrm{m}^{2} \text { and } \\
\text { immunosuppressive } \\
\text { medication was } \\
\text { continued }\end{array}$ & $\begin{array}{l}\text { 35\% (17/49) EBV } \\
>1,000 \text { geq/mL } \\
4 \%(2 / 49) \text { EBV PTLD }\end{array}$ & $\begin{array}{l}\text { 55\% (27/49) EBV viremia. } \\
\text { 14/15 treated patients without EBV } \\
\text { PTLD had a complete and sustained } \\
\text { response. } \\
\text { EBV DNA in plasma became } \\
\text { undetectable after a median of } 8 \text { days } \\
\text { (range, 1-46 days). } \\
\text { Median time to EBV reactivation: } 112 \\
\text { days (range, 39-189 days) after HSCT } \\
\text { Median EBV DNA level measured } \\
2100 \text { geq/mL (range, 500-14,000) prior } \\
\text { to admission and a median of } 3 \text { days } \\
\text { (range, } 1-14 \text { ) elapsed between that day } \\
\text { and initiation of pre-emptive therapy. } \\
\text { No Recurrent reactivations. }\end{array}$ \\
\hline $\begin{array}{l}\text { Wagner et al. } \\
2004^{16}\end{array}$ & $\begin{array}{l}\mathrm{N}=111 \\
\text { Conditioning = Fully } \\
\text { ablative CyAraCTBI, } \\
\text { BuCyAraC or CyTBI } \\
\text { GVHD Px = Full Px not } \\
\text { reported, ATG (type or dose } \\
\text { not reported) either alone or } \\
\text { with T-cell and/or B-cell } \\
\text { depletion, or alemtuzumab } \\
\text { (dose not reported). }\end{array}$ & Second weekly & PBMC & 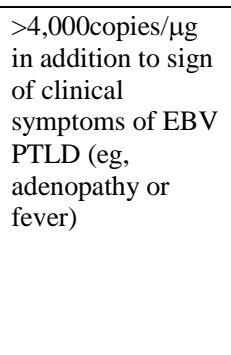 & $\begin{array}{l}\text { Pre-emptive rituximab } \\
375 \mathrm{mg} / \mathrm{m}^{2} \text { weekly or } \\
\text { CTLs }\end{array}$ & $\begin{array}{l}\text { 29\% (25/85) EBV } \\
>4,000 \text { copies/ } / \text { g (without } \\
\text { clinical symptoms and were } \\
\text { NOT pre-emptively treated) } \\
\text { 9.4\% (8/85) EBV PTLD } \\
\text { (developed prolonged fever, } \\
\text { lymphadenopathy, or other } \\
\text { symptoms or imaging } \\
\text { findings) }\end{array}$ & $\begin{array}{l}9 / 25 \text { patients had EBV load elevated } \\
\text { only once and was not accompanied by } \\
\text { clinical symptoms, these normalized } \\
\text { spontaneously. } \\
16 \text { of these } 25 \text { had EBV DNA levels } \\
>4,000 \text { copies } / \mu \text { g on } 2 \text { or more } \\
\text { occasions. } \\
\text { Of the } 8 \text { affected, two received CTLs, } \\
5 \text { received rituximab ( } 1-4 \text { doses of } \\
\left.375 \mathrm{mg} / \mathrm{m}^{2}\right) \text {, and } 1 \text { patient received }\end{array}$ \\
\hline
\end{tabular}

This article is protected by copyright. All rights reserved. 


\begin{tabular}{|c|c|c|c|c|c|c|c|}
\hline & $\begin{array}{l}\text { (85/111 had at least } 4 \mathrm{EBV} \\
\text { results for analysis, } 26 \\
\text { excluded) }\end{array}$ & & & & & & $\begin{array}{l}\text { CTLs and rituximab (1 dose of } \\
\left.375 \mathrm{mg} / \mathrm{m}^{2}\right) \text {. In all } 8 \text { patients, clinical } \\
\text { symptoms associated with increased } \\
\text { EBV load resolved. }\end{array}$ \\
\hline $\begin{array}{l}\text { Deeg et al. } \\
2006^{60}\end{array}$ & $\begin{array}{l}\mathrm{N}=56 \\
\text { Conditioning }=\mathrm{Bu} / \mathrm{Cy} \\
\text { GVHD Px = MTX, CSP, } \\
\text { ATG-T was 4.5-6mg } / \mathrm{kg}\end{array}$ & $\begin{array}{l}\text { Twice weekly to day } \\
42\end{array}$ & Plasma & $>1,000$ copies $/ \mathrm{mL}$ & $\begin{array}{l}\text { Pre-emptive rituximab } \\
375 \mathrm{mg} / \mathrm{m}^{2}\end{array}$ & $\begin{array}{l}\text { 1.7\% (1/56) EBV } \\
>1,000 \text { copies/mL (1/15 in } \\
6 \mathrm{mg} / \mathrm{kg} \text { ATG-T) } \\
\text { No EBV PTLD }\end{array}$ & \\
\hline $\begin{array}{l}\text { Carpenter et } \\
\text { al. } 2010^{61}\end{array}$ & $\begin{array}{l}\mathrm{N}=111 \\
\text { Conditioning = RIC FluMel } \\
\text { or CyTBI } \\
\text { GVHD Px = CSP, RIC: } \\
\text { alemtuzumab } 100 \text { mg-20mg. } \\
\text { CyTBI: } 20 \text { mg alemtuzumab } \\
\text { "in the bag." }\end{array}$ & $\begin{array}{l}\text { Weekly until day } \\
100 \text {, and then at } \\
\text { follow up }\end{array}$ & Whole blood & $\begin{array}{l}>40,000 \\
\text { copies } / \mathrm{mL}\end{array}$ & $\begin{array}{l}\text { Pre-emptive rituximab } \\
375 \mathrm{mg} / \mathrm{m}^{2} \text { (single } \\
\text { infusion) and } \\
\text { withdrawal of immune } \\
\text { suppression }\end{array}$ & 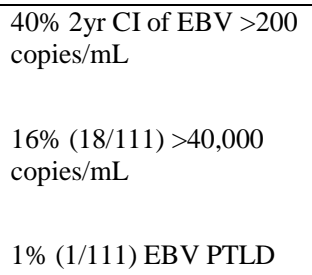 & \\
\hline $\begin{array}{l}\text { Worth et al. } \\
2011^{35}\end{array}$ & $\begin{array}{l}\mathrm{N}=70 \\
\text { Conditioning = RIC FluMel } \\
\text { GVHD Px = CSP alone (sib) } \\
\text { or CSP + MMF, } \\
\text { alemtuzumab } 0.5-1 \mathrm{mg} / \mathrm{kg} .\end{array}$ & $\begin{array}{l}\text { Weekly until } \\
\text { recovery of } \\
\text { circulating CD4+ T- } \\
\text { cells to }>0.3 \times 10^{9} / \mathrm{L} \text {. }\end{array}$ & Whole blood & $\begin{array}{l}>40,000 \text { copies } / \mathrm{ml} \\
\text { on two } \\
\text { consecutive } \\
\text { occasions with } \\
\text { CD4+ T-cells to } \\
<0.3 \times 10^{9} / \mathrm{L}\end{array}$ & $\begin{array}{l}\text { Pre-emptive rituximab } \\
375 \mathrm{mg} / \mathrm{m}^{2} \text { weekly for } 4 \\
\text { weeks and } \\
\text { immunosuppression } \\
\text { was reduced if there } \\
\text { was no active GVHD }\end{array}$ & $\begin{array}{l}\text { 53\% (37/70) EBV } \\
>1,000 \text { copies/mL } \\
\text { 27\% (20/70) progressed to } \\
>40,000 \text { copies/ml } \\
\text { 1.4\% (1/70) EBV PTLD }\end{array}$ & $\begin{array}{l}\text { 6/70 patients had viremia } \\
>40,000 \text { copies } / \mathrm{ml} \text { but were not treated } \\
\text { with rituximab on the basis of having } \\
\text { T-cell counts }>0.3 \times 10^{9} / \mathrm{L} \text { and none } \\
\text { developed EBV PTLD. }\end{array}$ \\
\hline $\begin{array}{l}\text { Wang et al. } \\
2014^{62}\end{array}$ & $\begin{array}{l}\mathrm{N}=224 \text { (haploidentical } \\
\text { donors) } \\
\text { Conditioning = Ara- } \\
\text { C/Bu/Cy/Simustine or } \\
\text { TBI/Cy/Simustine } \\
\text { GVHD Px = CSP, MMF, } \\
\text { MTX, ATG-T (N= } 112 \\
6 \mathrm{mg} / \mathrm{kg} \text { vs } 11210 \mathrm{mg} / \mathrm{kg} \text { ) }\end{array}$ & $\begin{array}{l}\text { Weekly until day } \\
100 \text {, then once every } \\
2 \text { weeks until day } \\
180 \text {, followed by } \\
\text { once every month } \\
\text { until } 1 \text { year after } \\
\text { HSCT or twice } \\
\text { weekly if any } \\
\text { positive level }\end{array}$ & Not reported & $>1,000$ copies $/ \mathrm{mL}$ & $\begin{array}{l}\text { Pre-emptive rituximab } \\
\text { (dose and duration not } \\
\text { reported) }\end{array}$ & $\begin{array}{l}\text { 6mg/kg ATG-T EBV: } \\
\text { 10\% (11/112) } \\
>1,000 \text { copies/mL } \\
\text { 2\% EBV PTLD } \\
\text { 10mg/kg ATG-T EBV: } \\
\text { 25\% (28/112) } \\
>1,000 \text { copies/mL }\end{array}$ & \\
\hline
\end{tabular}




\begin{tabular}{|c|c|c|c|c|c|c|c|}
\hline & & & & & & 8\% EBV PTLD & \\
\hline $\begin{array}{l}\text { Michallet et } \\
\text { al. } 2016^{34}\end{array}$ & $\begin{array}{l}\mathrm{N}=359 \\
\text { Conditioning= 171 } \\
\text { myeloablative, } 188 \text { RIC } \\
\text { GVHD Px = not reported, } \\
\text { ATG type or usage rate not } \\
\text { reported however reported } \\
\text { that ATG was used. }\end{array}$ & $\begin{array}{l}\text { Weekly for } 3 \\
\text { months }\end{array}$ & Whole blood & $\begin{array}{l}>1,000 / \\
>10,000 \text { copies } / \mathrm{mL}\end{array}$ & $\begin{array}{l}\text { >1,000copies/mL: } \\
\text { Reduce immune } \\
\text { suppression at } \\
\text { >10,000copies/ml: } \\
\text { Pre-emptive rituximab } \\
375 \mathrm{mg} / \mathrm{m}^{2} \text { four } \\
\text { injections weekly }\end{array}$ & $\begin{array}{l}62 \% \text { (222/359) EBV } \\
>1,000 \text { copies/mL } \\
16 \% \text { (35/222) EBV } \\
>10,000 \text { copies/mL } \\
\text { No EBV PTLD }\end{array}$ & $\begin{array}{l}\text { Median time of treatment was } 55 \text { days } \\
\text { after transplantation. } \\
\text { Median of } 5 \text { rituximab infusions. }\end{array}$ \\
\hline $\begin{array}{l}\text { Burns et al. } \\
2016^{21}\end{array}$ & $\begin{array}{l}\mathrm{N}=186 \\
\text { Conditioning = FluMel or } \\
\text { CyTBI } \\
\text { GVHD Px = CSP +/- MTX } \\
\text { or MMF, alemtuzumab } 10 \\
\text { mg D-7 to D-3 }\end{array}$ & $\begin{array}{l}\text { Weekly to second } \\
\text { weekly for the first } 6 \\
\text { months, } \\
\text { intermittently } \\
\text { thereafter }\end{array}$ & Whole blood & $>20,000$ geq $/ \mathrm{mL}$ & $\begin{array}{l}\text { Pre-emptive rituximab } \\
375 \mathrm{mg} / \mathrm{m}^{2} \text { up to } 4 \\
\text { weekly infusions }\end{array}$ & $\begin{array}{l}18 \%(38 / 186) \mathrm{EBV} \\
>20,0000 \mathrm{geq} / \mathrm{mL} \\
\\
4.3 \%(8 / 186) \text { EBV PTLD }\end{array}$ & $\begin{array}{l}48 \% \text { Cumulative incidence of EBV } \\
>500 \text { geq/mL. } \\
5 / 8 \text { EBV PTLD (63\%) had B } \\
\text { symptoms documented at presentation } \\
\text { and } 7 / 8 \text { ( } 88 \% \text { ) had stage } \geqslant 3 \text { disease. } \\
\text { Of these, all } 30 \text { without evidence of } \\
\text { PTLD, and 5/8 (63\%) with PTLD } \\
\text { responded to therapy. } \\
\text { Median time from EBV load >20 } \\
\text { 000copies/mL and radiographically } \\
\text { documented PTLD was } 7 \text { days (range } \\
1-16 \text { days). } \\
\text { Additionally, only } 1 / 25 \text { ( } 4 \% \text { ) patients } \\
\text { who received rituximab within } 6 \\
\text { months before transplant (for primary } \\
\text { B-cell malignancy) reactivated EBV in } \\
\text { the first year. }\end{array}$ \\
\hline $\begin{array}{l}\text { Jain et al. } \\
2019^{32,33}\end{array}$ & $\begin{array}{l}\mathrm{N}=488 \\
\text { Conditioning = } \\
\text { myeloablative and non- } \\
\text { myeloablative } \\
\text { GVHD Px = included a } \\
\text { selection of TAC, MMF, } \\
\text { MTX frequency not } \\
\text { reported. ATG-T 2.5- }\end{array}$ & $\begin{array}{l}\text { Weekly until day } \\
100 \text {, or beyond this } \\
\text { if GVHD, } \\
\text { immunosuppressants } \\
\text { or previous EBV } \\
\text { PTLD. }\end{array}$ & Whole blood & $\begin{array}{l}>2,000 \text { copies } / \mathrm{mL} \\
\text { and continues to } \\
\text { rise on a weekly } \\
\text { basis; } \\
\text { OR } \\
2,000- \\
5,000 \text { copies } / \mathrm{mL} \\
\text { and considered }\end{array}$ & $\begin{array}{l}\text { Pre-emptive rituximab } \\
375 \mathrm{mg} / \mathrm{m}^{2} \text { weekly }\end{array}$ & $\begin{array}{l}\text { 14\% (67/488) EBV } \\
\text { reactivations as per criteria } \\
1.4 \%(7 / 488) \text { EBV PTLD }\end{array}$ & $\begin{array}{l}\text { Median time to detection of EBV } \\
\text { reactivation from HSCT was } 34 \text { (range } \\
\text { 13-602) days. } \\
\text { Median level of EBV copy number } \\
\text { detected was 10,400 copies/mL (range } \\
2,000-645,000 \text { ). }\end{array}$ \\
\hline
\end{tabular}




\begin{tabular}{|c|c|c|c|c|c|c|c|}
\hline & $\begin{array}{l}7.5 \mathrm{mg} / \mathrm{kg} \text { in 306/488 } \\
\text { patients }\end{array}$ & $\begin{array}{l}\text { Repeat testing every } \\
3-5 \text { days after } \\
\text { reactivation }\end{array}$ & & $\begin{array}{l}\text { high risk of EBV } \\
\text { reactivation; } \\
\text { OR } \\
>5,000 \text { copies } / \mathrm{mL}\end{array}$ & & & $\begin{array}{l}\text { Median EBV level at which rituximab } \\
\text { was started was 8,360 (range 2,000- } \\
645,000 \text { ) copies/mL. } \\
\text { Of the } 7 \text { patients who developed EBV } \\
\text { PTLD, } 1 \text { developed post rituximab. } 6 \\
\text { developed prior to initiation of } \\
\text { rituximab. }\end{array}$ \\
\hline \multicolumn{8}{|c|}{ Prophylaxis with rituximab } \\
\hline $\begin{array}{l}\text { Dominietto et } \\
\text { al. } 2012^{37}\end{array}$ & $\begin{array}{l}\mathrm{N}=123 \\
\text { Conditioning = CyTBI or } \\
\text { ThioCy } \\
\text { GVHD Px = CSP, ATG-T } \\
6-10 \mathrm{mg} / \mathrm{kg}, \text { rituximab } \\
200 \mathrm{mg} \text { D+5 in } 55 \text { patients } \\
\text { (versus } 68 \text { patients without } \\
\text { rituximab) }\end{array}$ & $\begin{array}{l}\text { Weekly from D+15 } \\
\text { to } \mathrm{D}+100 .\end{array}$ & PBMC & $>1,000 / 10^{5}$ cells & $\begin{array}{l}\text { Prophylactic rituximab } \\
\text { at fixed dose of } 200 \mathrm{mg} \\
\text { for all patients was } \\
\text { administered on D }+5 \text {. } \\
\text { EBV copies }<1,000 / 10^{5} \\
\text { cells had CSP dose } \\
\text { reduced by } 50 \% \text { and } \\
\text { were monitored. } \\
\text { Patients with EBV } \\
\text { copies }>1000 / 10^{5} \text { cells, } \\
\text { had their CSP } \\
\text { discontinued and } \\
\text { rituximab } 375 \mathrm{mg} / \mathrm{m}^{2} \text {. } \\
\text { Patients who did not } \\
\text { clear EBV from } \\
\text { peripheral blood in } 1 \\
\text { week, received a second } \\
\text { dose of rituximab } 375 \\
\text { mg } / \mathrm{m}^{2}\end{array}$ & $\begin{array}{l}\text { Prophylactic rituximab: } \\
14 \%(8 / 55) \text { EBV >1,000 } \\
\text { copies } / 10^{5} \text { cells } \\
\text { No EBV PTLD } \\
\text { Control: } \\
49 \% \text { ( } 33 / 68) \text { EBV >1,000 } \\
\text { copies } / 10^{5} \text { cells, } \mathrm{P}=0.0001 \\
\text { 2.9\% ( } 2 / 68 \text { ) developed a } \\
\text { lethal EBV PTLD, } \mathrm{P}=0.3\end{array}$ & $\begin{array}{l}\text { Prophylactic rituximab demonstrated } \\
56 \% \text { (31/55) EBV viremia compared } \\
\text { to } 85 \% \text { (58/68) in the control group } \\
\mathrm{P}=0.0004 \text {. } \\
\text { Additionally, the cumulative incidence } \\
\text { of grade II-IV acute GvHD was } \\
\text { significantly reduced in rituximab } \\
\text { patients ( } 20 \text { vs } 38 \%, \mathrm{P}=0.02) \text {. Chronic } \\
\text { GvHD was comparable. There was a } \\
\text { trend for a survival advantage for } \\
\text { patients receiving rituximab ( } 46 \text { vs } \\
40 \%, \mathrm{P}=0.1 \text { ), mainly because of lower } \\
\text { transplant mortality ( } 25 \text { vs } 37 \% \text {, } \\
\mathrm{P}=0.1 \text { ). }\end{array}$ \\
\hline $\begin{array}{l}\text { Peccatori et } \\
\text { al. } 2015^{38}\end{array}$ & $\begin{array}{l}\mathrm{N}=121 \text { (haploidentical } \\
\text { donors) } \\
\text { Conditioning = TreoFlu } \\
\text { GVHD Px = SIR, MMF, } \\
\text { ATG-F (30mg/kg), } \\
\text { Rituximab 500mg D-1 }\end{array}$ & $\begin{array}{l}\text { Weekly, start date } \\
\text { and duration were } \\
\text { not reported }\end{array}$ & Plasma & $\begin{array}{l}\text { Definition of EBV } \\
\text { "high-titre”, or } \\
\text { pre-emptive } \\
\text { therapy not } \\
\text { reported. }\end{array}$ & $\begin{array}{l}\text { Prophylactic rituximab } \\
\text { administered as a fixed } \\
500 \text { mg dose on day }-1 .\end{array}$ & No EBV PTLD & $\begin{array}{l}\text { No "high-titer" EBV viremia was } \\
\text { documented. Authors comment this is } \\
\text { possibly because of the combined } \\
\text { effect of rapid T-cell recovery and } \\
\text { inclusion of rituximab in the } \\
\text { conditioning regimen. }\end{array}$ \\
\hline $\begin{array}{l}\text { Van Besien et } \\
\text { al. } 2019^{39}\end{array}$ & $\begin{array}{l}\mathrm{N}=198 \text { (halpo-cord donor, } \\
\text { supplemented by CD34 }\end{array}$ & $\begin{array}{l}\text { Twice weekly } \\
\text { during }\end{array}$ & Not reported & $\begin{array}{l}\text { Not reported, } \\
\text { PTLD reported }\end{array}$ & $\begin{array}{l}\text { Prophylactic rituximab } \\
375 \mathrm{mg} / \mathrm{m}^{2} \text { was }\end{array}$ & $\begin{array}{l}\text { Prior rituximab: } \\
\text { No EBV PTLD }\end{array}$ & $\begin{array}{l}2 \%(1 / 51) \text { EBV viremia }(>200 \\
\text { copies/mL) in the prior rituximab }\end{array}$ \\
\hline
\end{tabular}




\begin{tabular}{|c|c|c|c|c|c|c|c|}
\hline & $\begin{array}{l}\text { selected third-party cells to } \\
\text { accelerate recovery) } \\
\text { Conditioning = most } \\
\text { commonly FluMel+/-TBI } \\
\text { GVHD Px = TAC, MMF, } \\
\text { ATG } 4.5-6 \mathrm{mg} / \mathrm{kg} \text {, rituximab } \\
375 \mathrm{mg} / \mathrm{m}^{2}, 2 \text { weeks prior to } \\
\text { HSCT (n=38), prior } \\
\text { treatment with rituximab } \\
(\mathrm{n}=13), \text { no rituximab } \\
(\mathrm{n}=147)\end{array}$ & $\begin{array}{l}\text { hospitalization, then } \\
\text { weekly for the first } \\
100 \text { days, then } \\
\text { second weekly until } \\
\text { day180 or as } \\
\text { clinically indicated }\end{array}$ & & $\begin{array}{l}\text { based on "rapid } \\
\text { increasing EBV } \\
\text { levels", positive } \\
\text { PET scan and } \\
\text { biopsy proven } \\
\text { PTLD }\end{array}$ & $\begin{array}{l}\text { administered } 2 \text { weeks } \\
\text { prior to HSCT }(\mathrm{n}=38) \\
\text { unless prior treatment } \\
\text { with rituximab was } \\
\text { given for primary B-cell } \\
\text { malignancy ( } \mathrm{n}=13) \text {. }\end{array}$ & $\begin{array}{l}\text { No prior rituximab: } \\
\text { 12\% (16/146) EBV PTLD }\end{array}$ & $\begin{array}{l}\text { group, compared to } 18 \% \text { (27/146), } \\
\text { P=0.004. } \\
\text { Of the 16/146 who developed PTLD, } \\
\text { 11/16 were biopsy proven, and 5/16 } \\
\text { were treated based on rapidly } \\
\text { increasing EBV viremia and positive } \\
\text { PET scan. } 9 / 16 \text { responded to single } \\
\text { agent rituximab treatment, } 7 / 16 \\
\text { required additional treatment with } \\
\text { chemotherapy, and one also received } \\
\text { adoptive cellular therapy with EBV } \\
\text { directed third-party donor cells. 5/16 } \\
\text { patients died from PTLD and one died } \\
\text { from chemotherapy-induced sepsis. }\end{array}$ \\
\hline \multicolumn{8}{|c|}{ Cytotoxic T-Lymphocytes (CTLs) } \\
\hline $\begin{array}{l}\text { Heslop et al. } \\
2010^{46}\end{array}$ & $\begin{array}{l}\mathrm{N}=101 \text { CTL prophylaxis } \\
\text { Conditioning = Not reported } \\
\text { GVHD Px = CD6+ and } \\
\text { CD8+T-cell-depletion in } \\
\text { 90/101 (90\%) }\end{array}$ & $\begin{array}{l}\text { Weekly, start date } \\
\text { and duration were } \\
\text { not reported }\end{array}$ & PBMC & N/A & $\begin{array}{l}\text { Prophylactic EBV } \\
\text { CTLs were } \\
\text { administered with } 1 \\
\text { dose of } 2 \times 10^{7} \text { cells/m² } \\
\text { to the majority of } \\
\text { patients }\end{array}$ & No EBV PTLD & 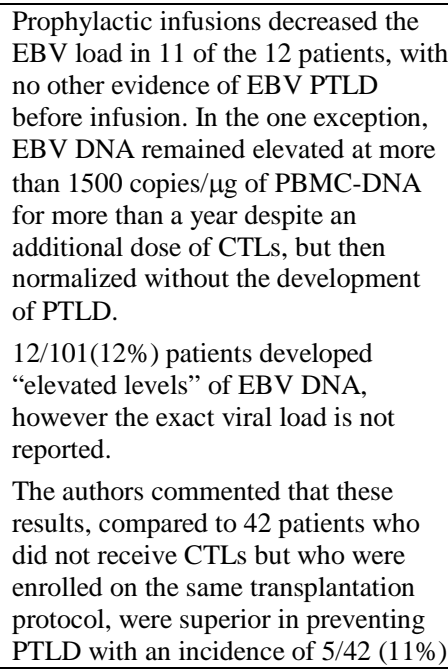 \\
\hline
\end{tabular}




\begin{tabular}{|l|l|l|l|l|l|}
\hline & & & in the group who did not receive & CTLs. \\
\hline $\begin{array}{l}\text { Abbreviations: Cy: Cyclophosphamide, TBI: Total Body Irradiation, GVHD: Graft Versus Host Disease, Px: Prophylaxis, CSP: Cyclosporin, TCD: T-cell Depletion, ATG: Antithymocyte Globulin, ATG-T: } \\
\text { Thymoglobulin }\end{array}$ \\
Fludarabine, Mel: Melithymocyte Globulin, ATG-F: Fresenius ${ }^{\mathrm{TM}}$ Antithymocyte Globulin, AraC: Cytarabine, Bu: Busulfan, MMF: Mycophenolate, MTX: Methotrexate, RIC: Reduced Intensity Conditioning, Flu:
\end{tabular}




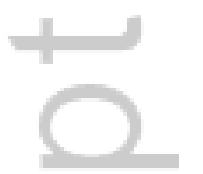

This article is protected by copyright. All rights reserved. 


\section{University Library}

\section{- M M I N E R VA \\ A gateway to Melbourne's research publications}

Minerva Access is the Institutional Repository of The University of Melbourne

Author/s:

Lindsay, J;Yong, MK;Greenwood, M;Kong, DCM;Chen, SCA;Rawlinson, W;Slavin, M

Title:

Epstein-Barr virus related post-transplant lymphoproliferative disorder prevention strategies in allogeneic hematopoietic stem cell transplantation

Date:

2020-04-17

Citation:

Lindsay, J., Yong, M. K., Greenwood, M., Kong, D. C. M., Chen, S. C. A., Rawlinson, W. \& Slavin, M. (2020). Epstein-Barr virus related post-transplant lymphoproliferative disorder prevention strategies in allogeneic hematopoietic stem cell transplantation. REVIEWS IN MEDICAL VIROLOGY, 30 (4), https://doi.org/10.1002/rmv.2108.

Persistent Link:

http://hdl.handle.net/11343/275651 